\title{
Analisis persepsi peserta didik terhadap bimbingan dan konseling di SMAN 1 Tapan
}

\author{
Ruri Afria Nursa a,1,* \\ a Universitas Muhammadiyah Sumatera Barat, 1. Pasir Jambak No.4, Pasie Nan Tigo, Koto Tangah, Padang, Sumatera Barat 25172, Indonesia \\ 1 afrianursaruri@gmail.com \\ * corresponding author
}

\section{ARTICLE INFO}

\section{Article History}

Received: 30 of January 202

Revised: 30 of March 2021

Accepted: 28 of April 2021

Keyword: Student perception, Guidance and Counseling

Kata Kunci: Persepsi peserta didik, Bimbingan dan konseling

\begin{abstract}
This study aims to determine students' perceptions of counseling guidance at SMAN 1 Basa Ampek Balai Tapan. This research is a quantitative descriptive study with a population of all students in SMAN 1 BAB Tapan. Sample citing is done by cluster random sampling which is taking classes X, XI and XII with a total sample of 88 students. The instrument in this study questionnaire students' perceptions of counseling guidance consisting of 20 items. Data analysis using the calculation of the mean and SD so that the scores of students can be categorized as perceptions of very agree, agree, moderate, disagree and strongly disagree. The results of this study include: the percentage of the number of students who have a category of strongly agreeing with guidance and counseling is $7.95 \%$, agreeing with guidance and counseling $52.27 \%$, while there is guidance and counseling $32.95 \%$, disagreeing with guidance and counseling $5.68 \%$, and strongly disagree with guidance and counseling $1.15 \%$. The perception occurs as a result of external factors, namely the situation of counseling guidance services and internal factors of the characteristics of students.
\end{abstract}

\section{ABSTRAK}

Penelitian ini bertujuan untuk mengetahui persepsi peserta didik terhadap bimbingan konseling di SMAN 1 Basa Ampek Balai Tapan. Penelitian ini merupakan penelitian deskriptif kuantitatif dengan populasi seluruh peserta didik di SMAN 1 BAB Tapan. Pengutipan sampel dilakukan dengan cara cluster random sampling yakni mengambil kelas X, XI dan XII dengan jumlah sampel 88 peserta didik. Instrumen dalam penelitian ini angket persepsi peserta didik terhadap bimbingan konseling yang terdiri dari 20 item. Analisis data menggunakan perhitungan mean dan SD sehingga skor peserta didik dapat dikategorikan persepsi sangat setuju, setuju, sedang, tidak setuju dan sangat tidak setuju. Hasil penelitian ini yaitu: persentase jumlah peserta didik yang memiliki kategori sangat setuju adanya bimbingan dan konseling sebesar $7,95 \%$, setuju adanya bimbingan dan konseling $52,27 \%$, sedang adanya bimbingan dan konseling 32,95\%, tidak setuju adanya bimbingan dan konseling 5,68\%, dan sangat tidak setuju adanya bimbingan dan konseling $1.15 \%$. Terjadinya persepsi termaktub akibat faktor eksternal yaitu dari situasi layanan bimbingan konseling dan faktor internal dari karakteristik peserta didik.

This is an open access article under the CC-BY-SA license. 


\section{Pendahuluan}

Konselor atau pembimbing ialah salah satu anggota guru yang cukup besar peranannya dalam menyelenggarakan pendidikan yang disebut dengan guru bimbingan konseling (BK). Bimbingan Konseling merupakan jenis layanan dan kegiatan pendukung, berdasarkan norma-norma yang berlaku untuk membantu peserta didik agar mandiri dan berkembang secara optimal baik secara perorangan maupun kelompok seperti bimbingan sosial, bimbingan pribadi, bimbingan karir dan bimbingan belajar (Pedoman Khusus Bimbingan Konseling, 2004). Tetapi tidak bisa dihindari kenyataan yang terjadi sekarang banyaknya masalah-masalah yang ada di lembaga pendidikan, yang mana pekerjaan bimbingan dan konseling tidak memadai. Beraneka macam masalah seperti tawuran antar peserta didik dan kriminal yang dilakukan peserta didik dikabarkan di media publik akhir-akhir ini. Apalagi berbagai kasus Klitih yang juga banyak melibatkan peserta didik. Perilaku agresif yang dilakukan para kalangan remaja saat ini dapat merugikan remaja itu sendiri, keluarga dan lingkungan sekitar mereka karena perilaku agresif yang dilakukan remaja sudah mengarah kepada tindakan kriminal serta sudah sangat mengkhawatirkan [1].

Bimbingan dan konseling sangat diperlukan oleh peserta didik tetapi realita yang ditemukan di lapangan bahwa bimbingan dan konseling sedikit berperan dalam menjalankan tugasnya. Sebagian dari peserta didik hanya akan menceritakan masalah ketika mereka dihimbau oleh guru bimbingan dan konseling, padahal layanan bimbingan dan konseling tidak hanya melihat masalah dari perspektif peserta didik [2] menimbulkan persepsi yang kurang tepat terhadap bimbingan dan konseling. Sehingga, bimbingan dan konseling di sekolah tidak satu-satunya bagian yang mesti bertanggung jawab akan kejadian tersebut. Keluarga dalam hal ini juga harus mengambil peran sebagai pola asuh orang tua karena sangat berpengaruh terhadap perkembangan anak dalam pembentukan karakter atau perilaku anak juga lingkungan sosial dimana anak tersebut tinggal [3].

Seperti itu pula dalam melihat persepsi yang membentuk reaksi sebab sebelum timbulnya tumpuan, intensi, kelakuan, dan perbuatan juga difungsikan model yang sama. Persepsi merupakan suatu cara terkonsolidasi dalam diri seseorang terhadap fenomena yang dipersepsi, sehingga membangkitkan penilaian [4]. Prosedur tersebut terjadi pengorganisasian, pengumpulan, tafsiran dan pemaknaan terhadap rangsangan yang ada sehingga menimbulkan penilaian [4]. Penilaian yang mencuat konsekuensi oleh faktor yang berasal dari dalam diri seseorang yang memberi penilaian dan juga pengetahuan yang telah dimiliki individu sebelumnya serta lingkungan sosial. Pada dasarnya bahwa nilai-nilai yang ada pada diri manusia dapat dilihat dari tingkah laku [5]. Peserta didik SMA dalam rekognisi bimbingan konseling di sekolah atau madrasahnya juga tidak terlepas dari konsekuensi tertulis. Bersumber dari kajian psikologi kognitif, persepsi tidak mesti linear dengan sikap [4]. Maksudnya, perilaku aktual individu terhadap seseorang maupun sesuatu belum tercapai memberi penanda bahwa persepsi seseorang terhadap seseorang maupun sesuatu itu pun positif. Keadaan ini lantaran aturan khusus yang dimiliki perorangan sehingga menimbulkan dismilaritas jarak persepsi dan tabiat.

Sejauh penelusuran peneliti terhadap berbagai sumber pustaka, penelitian ini lebih fokus membahas analisis persepsi peserta didik terhadap bimbingan koseling. Sedangkan, penelitian yang telah dilakukan oleh Laelatul Badriah dengan judul persepsi peserta didik terhadap guru Bimbingan dan Konseling di Madrasah Aliyah Ali Maksum. Penelitian yang dilakukan oleh Laelatul ini membahas persepsi peserta didik terhadap bimbingan dan konseling yang dilakukan di Madrasah. Penelitian tersebut berdasarkan adanya estimasi bahwasanya guru bimbingan konseling merupakan guru yang harus diwasapadai dan peserta didik menaksir bahwa seseorang yang kena analitis notulen guru BK ialah peserta didik yang mengalami persoalan. Dalam penelitian ini digunakan metode kualitatif. Subjek penelitian yaitu peserta didik perempuan dan guru BK. Pengutipan data memakai penjabaran gambaran kualitatif. Hasil dalam kaijian ini ialah persepsi siswa terhadap guru bimbingan dan konseling menerima baik dan positif [6].

Penelitian yang dilakukan oleh Busmayaril dan Heldayani dengan judul persepsi peserta didik terhadap aktualisasi bimbingan dan konseling di Sekolah Menengah Atas Negeri 1 Karya Penggawa Kabupaten Pesisir Barat. Metode telaah eksprimen menggunakan metode kualitatif memakai subjek telaah eksprimen 8 orang, diantaranya enam peserta didik, satu kepala sekolah, satu guru BK SMA Negeri 1 Karya Penggawa Kabupaten Pesisir Barat dari kelas sepuluh (X), sebelas (XI), dan dua belas (XII) memakai teknik snowball sampling. Pengambilan data-data 
menggunakan teknik wawancara yang menilik disusun bagi penelaah atau peneliti. Hasil penelaah memperlihatkan bahwa, persepsi peserta didik terhadap aktualisasi arahan konseling menyatakan persepsi peserta didik terhadap aktualisasi arahan dan konseling belum maksimal [7].

Berdasarkan hasil penelitian sebelumnya, dapat diambil suatu kesimpulan bahwa analisis persepsi antara peserta didik dan BK harus disamakan. Jika persepsi peserta didik terhadap konselor positif hal ini berarti orang yang memberi dampak terhadap bimbingan dan konseling dalam melakukan perannya, maka persepsi peserta didik terhadap bimbingan penyuluhan cenderung positif, sebaliknya jika analisis perserta didik terhadap arahan penyuluhan negatif, yang signifikan bahwa konselor atau arahan yang diberikan penyuluhan belum menjalankan perannya secara baik, maka persepsi peserta didik terhadap arahan penyuluhan cenderung tidak baik atau negatif.

Pada penelitian ini, peneliti ingin mengetahui lebih lanjut tentang persepsi peserta didik terhadap bimbingan dan konseling di SMA N 1 Basa Ampek Balai Tapan. Hasil penelitian ini diharapkan dapat memberikan deskripsi kegiatan bimbingan dan konseling di sekolah pada para stakeholder, penggiat pendidikan, dan pengelola sekolah.

\section{Metode}

\subsection{Rancangan penelitian}

Jenis penelitian ini adalah jenis penelitian deskriptif menggunakan rancangan penelitian kuantitatif. Penelitian deskriptif adalah suatu penelitian atau pengkajian yang berupaya menggambarkann suatu indikasi, perkara, kasus yang berlaku pada era sekarang [8]. Pendekatan kuantitatif adalah cara penanggulangan persoalan yang terprogram dan telaten melalui rancangan yang terkonstruksi selektif, pengumpulan data sebagai analitis terdominasi serta terarah atas kategorisasi ide yang disimpulkan sebagai induktif dan konteks justifikasi hipotesis secara empiris [9]. Dengan demikian telaah ekspirimen deskriptif kuantitatif adalah metode penelitian yang digunakan untuk meneliti populasi atau sampel tertentu, analisis data bersifat kuantitatif dengan tujuan untuk menguji hipotesis yang telah ditetapkan sesuai dengan kejadian yang terjadi saat sekarang.

\subsection{Sumber Data}

Menurut Sugiyono area umum terdiri dari tajuk, fenomena dan partikularitas terpilih yang ditetapkan bagi pengkaji yang akhirnya dideterminasikan disebut populasi [10]. Pengkajian ini mengambil lokasi di Kabupaten Pesisir Selatan Sumatera Barat khususnya di SMAN 1 BAB Tapan. Jumlah sampel yang diambil masing kelas yakni kelas sepuluh (X) terdapat 30 peserta didik, kelas sebelas (XI) sebanyak 29 peserta didik dan 29 peserta didik di kelas dua belas (XII). Jadi keseluruhan sampel dari kelas sepuluh (X), sebelas (XI), dan dua belas (XII) terdapat 88 Peserta didik. Adapun rincian peserta didik pada tabel 1:

Tabel 1. Sampel Penelitian

\begin{tabular}{|c|c|c|}
\hline No & Kelas & Jumlah peserta didik \\
\hline 1. & Kelas Sepuluh (X) & 30 Peserta didik \\
\hline 2. & Kelas Sebelas (XI) & 29 Peserta didik \\
\hline 3. & Kelas Dua Belas (XII) & 29 Peserta didik \\
\hline & Jumlah & 88 Peserta didik \\
\hline
\end{tabular}

Arikunto menyatakan bahwa sampel merupakan sebagaian atau wakil populasi yang diteliti [8]. Dalam penelitian ini peneliti memakai 88 sampel serta penelitian ini memakai teknik dengan cara cluster random sampling. Pengutipan spesimen data pada akar data serta evaluasi tertentu [11]. 


\subsection{Teknik Pengumpulan Data}

Instrumen yang dipakai dalam penelitian ini ada 2 ragam yaitu: daftar pertanyaan serta patokan interview. Daftar pertanyaan diajukan pada peserta didik untuk menelaah persepsi mereka tentang layanan bimbingan dan konseling yang menduga terjadinya perbedaan persepsi peserta didik. Sedangkan patokan interviu diajukan untuk mengetahui keterangan lebih akurat mengenai identitas para peserta didik sehingga menampakkan suatu pemahaman tertentu. Dalam melakukan wawancara, peneliti menggunakan patokan wawancara tentang berbagai asumsi peserta didik terhadap layanan bimbingan dan konseling selama ini, agar tidak beralih arah dari panduan yang telah direncanakan.

Hasil wawancara ini bisa dikembangkan agar mencapai data yang makin komprehensif [12]. Data yang didapatkan dari penelitian ini ialah data gambaran yang berawal dari penjabaran daftar pertanyaan yang berbentuk persentase sirkulasi persepsi peserta didik terhadap layanan bimbingan dan konseling. Dari gambaran data tersebut nantinya akan didefinisikan kedalam sebuah kesimpulan menyinggung keadaan persepsi peserta didik atas layanan bimbingan dan konseling di SMAN 1 BAB Tapan sebagai tempat dalam penelitian ini. akar data dari penelitian ini ialah beberapa diantara peserta didik kelas sepuluh hingga kelas dua belas yang diambil secara acak.

\subsection{Teknik Analisis Data}

Cara penjabaran data merupakan metode untuk menggarap data yang dibutuhkan dalam penelitian. Data yang ada harus diolah terlebih dahulu sebelum disimpulkan. Metode penjabaran data menggunakan bagian-bagian sebagai berikut: pertama, bagian persiapan, pada bagian ini aktivitas yang dikerjakan ialah: mengkondisi kelengkapan individualis responden (peserta didik), mengamati keseluruhan isi instrumen dalam pengisian data, mengkondisikan isian data, mengistimasi kuantitas segala kuesioner yang terkumpul; kedua, bagian tabulasi, aktivitas tabulasi ialah aktivitas yang membagikan data ke dalam tabel-tabel frekuensi agar memperenteng analitis menelaah data. aktivitas ini mencakup angka, yakni bagian pembalasan angka pada hasil kuesioner berlandaskan determinasi yang sudah permanen dengan menggunakan standar mean. Ketiga, bagian penerapan data, analisis data dilakukan berpatokan hasil kuesioner yang telah didapatkan. Tatkala diketahui selebaran persepsi peserta didik terhadap layanan bimbingan dan konseling berisi susunan persentase, pada akhirnya dapat menyimpulkan sebuah persepsi peserta didik.

\section{Hasil dan Pembahasan}

\subsection{Hasil Penelitian}

Deskripsi data persepsi analisis peserta didik terhadap bimbingan konseling yang terdiri dari 88 responden dapat dilihat pada tabel 2 . Sebagian besar peserta didik memilih persepsi sangat setuju terhadap bimbingan konseling yaitu sebesar 7,95\%, 52,27\% peserta didik memiliki persepsi setuju terhadap bimbingan konseling, lebih jelas dapat dilihat pada tabel 2:

\begin{tabular}{|c|c|c|c|}
\hline Interval Skor & Kategori & Frekuensi & Prosentase \\
\hline $61-67$ & Sangat setuju & 7 & $7,95 \%$ \\
\hline $54-60$ & Setuju & 46 & $52,27 \%$ \\
\hline $47-53$ & Sedang & 29 & $32,95 \%$ \\
\hline $40-46$ & Tidak setuju & 5 & $5,68 \%$ \\
\hline $33-39$ & Sangat tidak setuju & 1 & $1,15 \%$ \\
\hline Total & $\mathbf{8 8}$ & $\mathbf{1 0 0} \%$ & \\
\hline
\end{tabular}

Tabel 2. Distribusi frekuensi dan persentase 
Pada tabel 2 di atas, terlihat bahwa analisis persepsi peserta didik terhadap bimbingan konseling jika dilakukan penjumlahan skor, dengan menggunakan rumus hitungan diperoleh harga mean sebesar 53,67. Harga ini jika dikonsultasikan dengan klasifikasi analisis persepsi peserta didik, dapat dikatakan bahwa persepsi peserta didik terhadap bimbingan konseling ratarata setuju yaitu berkisar pada interval 54-60. Artinya, secara rata-rata peserta didik memiliki persepsi setuju adanya bimbingan konseling.

Menurut salah seorang guru bimbingan dan konseling di SMA Negeri 1 Basa Ampek Balai Tapan Kabupaten Pesisir Selatan Sumatera Barat, mempunyai keahlian dalam aktualisasi arahan konseling sangat bagus untuk peserta didik. Indeksnya nampak dari aktivitas guru bimbingan Konseling (BK) selama di sekolah dalam aktualisasi membuktikan norma yang bagus, sabar dalam melayani peserta didik serta menyampaikan arahan dan membimbing dalam memberikan layanan untuk mengatasi kasus-kasus yang dihadapi peserta didik. Namun, tidak semua guru bimbingan konseling berperan aktif dan sabar dalam memberi layanan konseling kepada peserta didik. Serta hanya memberi layanan kepada peserta didik yang terlibat masalah.

Guru bimbingan dan konseling menampakkan sikap dalam proses pelaksanan layanan ialah konselor atau pembimbing mermberikan layanan bagus bagi peserta didik atas bermacam kasus yang dihadapapi peserta didik serta memberi solusi dan arahan dengan tujuan agar dapat mencari solusi kasus-kasus yang dialami oleh peserta didik. Oleh sebab itu, seorang bimbingan dan konseling mengungkap bahwa pemahaman peserta didik terhadap bimbingan konseling di SMA Negeri 1 Basa Ampek Balai Tapan Kabupaten Pesisir Selatan Sumatera Barat ialah:

Pertama, peserta didik sulit mengungkapkan secara terbuka masalah yang sedang dihadapi kepada konselor atau pembimbing (guru BK) karena merasa kurang yakin kerahasiannya akan di umbar-umbarkan serta merasa malu jika persoalannya diketahui oleh orang lain. Kedua, peserta didik selalu takut kepada konselor dan menganggap akan dimarahi apabila mengetahui masalah yang sedang ia hadapi. Oleh sebab itu, kebanyakan peserta didik akan menghindar bahkan lari dari guru bimbingan konseling atau konselor. Ketiga, peserta menganggap bahwa bimbingan dan konseling itu hanya untuk orang bermasalah saja dan akan mendapat panggilan orang tua ke sekolah.

Hasil dari data yang didapatkan dari seluruh subjek penelitian menyebutkan bahwa pemberian bimbingan dianggap selaku ruang menyelesaikan masalah bagi peserta didik yang terlibat kasus, suka tawuran, nakal, bulliying serta sebagai tempat menasehati peserta didik yang tidak mematuhi aturan-aturan sekolah, dan identic dengan image guru bimbingan konseling yang menakutkan, sehingga hal tersebut ditakuti oleh peserta didik.

Untuk medisiplinkan peserta didik yang terlibat kasus-kasus dengan memberikan penjelasan kepada peserta didik, guru bimbingan dan konseling perlu memberikan penjelasan kepada peserta didik yang belum mengetahui secara menyeluruh tujuan bimbingan dan konseling dan masih sangat kausistik. Seandainya di sekolah belum ada konselor atau orang yang memberi bimbingan konseling sehingga tidak ada yang mengurusi secara spesifik dalam menangani peserta didik yang mengalami masalah baik dalam ranah lingkup pendidikan di sekolah, sosial, maupun keluarga. Sehingga fungsi dari konselor masih dipahami sebagai pengentasan masalah saja seperti memanggil peserta didik yang nakal dan mengintrogasinya.

\subsection{Pembahasan Penelitian.}

Persepsi merupakan cara seseorang mengasosiasikan dan menyampaikan makna terhadap sesuatu entitas atau stimulus yang memakai pendengarannya sehingga mampu mempresentasikan buah pikiran, sanggahan serta ideologi terhadap entitas yang dilihatnya kemungkinan akan mempengaruhi perbuatan seseorang. perangsangan diri berupa pandangan, perasaan, akal maupun perbuatan yang direncanakan berasosiasi terhadap manajemen pribadi berbarengan bersama capaian yang akan dituju [13].

Berdasarkan terhadap literatur yang relevan ditemukan beberapa defenisi terkait persepsi peserta didik. Menurut Robert J. Sternberg persepsi ialah cara peleburan analitis diri perorangan terhadap entitas apa yang dipahami, sehingga mencetuskan anggapan [4]. Sobur menyatakan Persepsi adalah banyaknya stimulus yang mempengaruhi indra ketika daalm proses sehingga 
menjadi sadar [14]. persepsi ialah suatu yang dapat dirasakan dan dilihat oleh peserta didik dalam memandang dan memaknainya [15] serta merupakan sebuah proses transformasi informasi ataupun pesan yang masuk ke dalam otak manusia [16]. Sependapat terhadap pengertian persepsi bagi Asrori ialah cara seseorang mengkonstruksikan, mendefenisikan serta menderma substansi stimulus yang membentuk pengetahuan yang diperoleh dari bagian perorangan itu sendri [17]. Persepsi peserta didik mengenai perilaku dan motivasi guru bimbingan konseling akan mempengaruhi perilaku dan persepsi peserta didik itu sendiri [18]. Selain itu, layanan yang diberikan oleh bimbingan konseling secara baik akan mempengaruhi persepsi peserta didik [19].

Dari beberapa penjelasan tersebut di atas, sehingga dapat peneliti simpulkan bahwasanya persepsi ialah suatu ideologi, pendapat maupun pemikiran yang mencuat atas pandangan seseorang terhadap suatu entitas maupun kejadian yang sudah pernah diamati lewat penglihatan. Defenisi dari pakar tersebut menunjukkan bahwa pengertian persepsi cenderung kepada pancaindra atau apa yg dilihatkan oleh masing-masing individu. Sependapat dengan teori di atas, Walgito pun mengutarakan bahwa persepsi membentuk cara konklusi dari inspeksi yang menginjak dengan cara penglihatan [20]. Suatu pandangan muncul karena adanya tanggapan terhadap suatu pandangan tersebut. Sehingga dari cara pandangan setiap perorangan maupun individu akan menyodorkan suatu tanggapan dari pandangan yang diperolehnya. Anggapan, perasaan, gagasan, ide, pengetahuan yang diperoleh maupun dengan istilah-istilah lain terhadap suatu individu perorangan yang menyampaikan anggapan itu sangat berpengaruh tatkala perorangan menanggapi.

Menurut Walgito ada beberapa faktor yang dapat mempengaruhi persepsi individu menurut Walgito bahwa persepsi maupun impresi ialah cara peninjauan perorangan yang bersumber dari bagian kesadaran. Impresi ini dipengaruhi oleh beberapa faktor pengetahuan, gagasan, serta pengalaman [21]. Individu mencermati suatu entitas psikis dengan penglihatannya sendiri yang kemudian disimpul dan dinilai dari kepribadianya. Sedangkan entitas psikis ini seperti masalah, kasus, perkara serta ide tertentu. Beberapa faktor tersebut melihatkan konstruksi dan bentuk terhadap apa yang diamati. Sedangkan pengetahuannya dan idenya melihat makna terhadap entitas psikis tersebut. Menggunakan bagian-bagian ini akan tercetus berupa konsep, kemudian ide-ide mengenai apa yang diamati. Berlandaskan dari etika dan adab yang dimiliki masingmasing perorangan akan terbentuk suatu ketetapan.

Rahmat mengemukakan bahwasanya persepsi individu dipengaruhi oleh faktor diantaranya: a) Faktor-faktor struktural berasal semata-mata dari sifat stimuli fisik dan efek saraf yang ditimbulkannya pada system saraf individu; b) Perhatian (attention); c) Faktor-faktor fungsional yang menentukan persepsi [22]. Sedangkan menurut Sobur persepsi ialah bagian proses dari psikologi terdiri dari faktor yang dapat mempengaruhinya ialah faktor struktural, faktor fungsional, faktor personal dan faktor situasional. a) Faktor situasional adalah berkaitan dengan bahasa non verbal misal, orang cemberut dipersepsikan marah, orang tersenyum dipersepsikan sedang bahagia; b) Faktor personal adalah berhubungan dengan motivasi, pengalaman, dan kepribadian; c) Faktor fungsional adalah bila mempersepsikan sesuatu hal maka akan memberikan tekanan atau hasil yang sesuai dengan apa yang diharapkan d) Faktor struktural adalah sesuatu yang dipersepsikan secara keseluruhan [14].

Peneliti menyimpulkan bahwa faktor yang mempengaruhi persepsi peserta didik ialah berdasarkan stimulus-stimulus yang dipandang secara kasat mata oleh masing-masing individu atau peserta didik, maka persepsi yang akan di hasilkan juga akan berbeda sesuai dengan stimulus yang dipersepsikan. Bimbingan dan konseling mestinya disusun serta dilakukan secara proaktif bagi konselor bertimbal balik terhadap konteks pekerjaan yang sudah pernah ditetapkan, sementara melangsungkan pengarahan secara individual, pengarahan kemasyarakatan, pengarahan menuntut ilmu serta pengarahan kedudukan maupun karir, dan menggunakan beberapa menjalankan pengarahan dan penyuluhan. Salah satunya ialah kondisi peserta didik yang butuh bimbangan dan konseling secara individual. Pengarahan secara perorangan merupakan pertolongan terhadap orang asing melalui berdialog maupun wawancara yang dilakaukan oleh seorang ahli atau yang disebut dengan konselor yang profesional tehadap konsumennya yang menuntut adanya hubungan, korelasi yang intens dan berupaya beriringan antara orang yang memberi pengarahan penyuluhan dengan konsumen agar memperoleh maksud penyuluhan seperti penyelesaian kasus, mencukupi keperluan maupun modifikasi kelakuan atau suatu perbuatan agar perorangan tersebut tumbuh kemampuannya secara menyeluruh serta 
pandai mengendalikan kesulitan-kesulitannya [23]. Melalui pelayanan bimbingan dan konseling diharapkan akan mampu untuk meningkatkan dan mengembangkan persepsi peserta didik secara tepat, yaitu dengan cara memberikan berbagai informasi kepada peserta didik secara langsung. Informasi yang diberikan secara tepat kepada peserta didik diharapkan akan lebih dapat mengembangkan persepsi yang baik atau positif terhadap bimbingan konseling, sehingga peserta didik dapat menentukan dan meningkatkan aspirasi bimbingan konseling secara tepat.

Berdasarkan hasil analisis data kajian ini membuktikan bahwa secara keseluruhan pandangan siswa maupun murid atas layanan bimbingan dan penyuluhan yang paling tinggi presentasenya berada pada kategori setuju. Dijelaskan dalam presentase kategori sebagai berikut: sangat setuju adanya bimbingan dan konseling sebesar 7,95\%, setuju adanya bimbingan dan konseling $52,27 \%$, sedang adanya bimbingan dan konseling 32,95\%, tidak setuju adanya bimbingan dan konseling 5,68\%, dan sangat tidak setuju adanya bimbingan dan konseling $1.15 \%$. Terjadinya persepsi termaktub akibat faktor eksternal yaitu dari situasi layanan bimbingan konseling dan faktor internal dari karakteristik peserta didik. Peserta didik memiliki persepsi yang setuju terhadap bimbingan konseling dikarenakan adanya persepsi bahwasanya melalui bimbingan dan konseling dapat mendukung peserta didik ketika melewati kasus-kasus yang ditanggungnya.

Bimbingan konseling merupakan sarana yang efektif untuk mencegah terjadinya bullying bahkan tawuran antar peserta didik. Menurut peserta didik dengan adanya bimbingan konseling yang ramah akan menjadikan mereka lebih terbuka dan selalu ingin berkonsultasi terhadap konselor. Tetapi faktor lain yang dapat mempengaruhi persepsi peserta didik terhadap pengarahan penyuluhan ialah bobot terhadap layanan, suasana, kondisi lingkungan, perorangan, kemampuan seseorang yang memberikan bimbingan dan konseling. Penyebab yang terlihat dari perorangan berasosiasi atas partikularitas individual. Sama halnya dikemukana Haris bahwasanya orang yang memberikan pengarahan penyuluhan di sekolah/madrasah yang sangat berpengalaman tidak sekedar cukup hanya memahami teori-teori yang ada serta sekedar menyampaikan pengarahan, melainkan mesti harus mempunyai karakteriktik yang menyejukkan agar terciptanya keharmonisan serta suasana hubungan yang akrab dengan peserta didik [24]. Suasana dan kondisi, pendapat Mappiare mengemukakan bahwasanya pengarahan dan penyuluhan diperlukan perorangan agar mengkondisikan kondisi yang bisa merangsangkan dengan maksud mencerna kemampuan sendiri serta kondisinya sehingga perorangan tersebut bisa melakukan opsinya yang tepat di era kaan datang [25].

Pada hasil observasi serta penjelasan di atas dapat penulis simpulkan bahwasanya peserta didik SMA N 1 Basa Ampek Balai (BAB) Tapan memiliki persepsi terhadap bimbingan dan konseling berada pada kelompok setuju. Perihal ini membuktikan bahwasanya peserta didik SMAN 1 BAB Tapan pada umumnya memiliki pandangan yang positif terhadap pengarahan penyuluhan, tentunya disupport dengan kapasitas lingkungan sekolah/madrasah yang kondusif kegiatan-kegiatan sekolah seperti support dari orang tua baik moril maupun materil serta kelengkapan sekolah/madrasah yang memuaskan juga kondisi lingkungan sekolah yang mendukung serta kondusif, rasa betah bagi peserta didik untuk menuntut ilmu dan berinteraksi sehingga peserta didik menyampaikan sesuatu pembandingan akan jasa bimbingan dan konseling yang dilakukan oleh guru bimbingan dan konseling di sekolah. Jasa pengarahan penyuluhan yang telah disusunkan di SMAN 1 BAB Tapan ialah jasa penempatan serta serta penyaluran, jasa orientasi, jasa informasi, jasa konten, jasa pengarahan penyuluhan baik perindividu maupun berkelompok, diskusi serta perantaraan. Beragam pelaksaan serta penerapan yang ditemukan atau terdapat beberapa masalah serta hambatan-hambatan yang dirasakan oleh bagian sekolah sehingga penerapannya sejauh ini belum maksimal. Perihal ini disebabkan adanya keterbatasanketerbatasan sarana dan prasarana dalam memberikan pelayanan bimbingan konseling di sekolah yang belum mencukupi dalam meningkatkan berbagai jalan masuk dalam memberikan pelayanan bimbingan konseling kepada peserta didik.

Dalam hubungan tertentu guru dapat memberikan pengetahuan terhadap peserta didik yang menerima pengarahan secara langsung tatap muka. Dalam hubungan tersebut kasus yang dihadapi oleh peserta didik didengar dengan baik serta dicarikan penyelesaiannya, seorang konselor sangat berharap akan adanya respon dari dalam diri peserta didik yang memiliki kasus. Sehingga menghadapi kasus-kasus yang ada, konseli atau peserta didik yang berhadapan dengan konselor dianggap selaku ikhtiar meladeni yang paling pokok terhadap aktualisasi guna penyelesaian kasus-kasus yang dihadapi seorang konseli. Apalagi diistilahkan bahwa penyuluhan 
mahkotanya dalam meneladani pengarahan secara komprehensif. Kondisi tersebut tampaknya penting bahwa sekiranya layanan penyuluhan telah memperuntukkan bantuannya, maka kasus dalam konseli akan terpecahkan dengan ampuh dan ikhtiar-ikhtiar pengarahan tinggal menirukan dan berkedudukan sebagai pengarahan. Menggunakan istilah lainnya bahwa konseling ialah layanan utama yang aktualisasinya menginginkan ketentuan serta kualitas sekolah/madrasah. Ketentuan layanan bimbingan dan konseling pada prinsipnya ialah menyediakan bimbingan kepada individual atau sekelompok individual agar mampu meningkatkan menjadi pribadi yang santun, berbudi, serta berprilaku terpuji. Dalam Zahara, Prayitno mengungkapkan bahwasanya bimbingan dan konseling memudahkan individual agar menjadi pribadi yang bermanfaat dalam kehidupan yang memiliki banyak pegetahuan, ide, wawasan, interpensi, penyesuaian, skill yang tepat berkaitan dengan diri sendiri dan lingkungan sekitar [26]. Pandangan peserta didik terhadap layanan pengarahan konseling akan baik apabila peserta didik merasa senang jika perhatian yang diberikan guru bimbingan konseling serta keterlibatan antara peserta didik dan orang yang memberi konseling atas mempertimbangkan serentak lewat interaksi diskusi sehingga mahir menyelesaikan masalah atau kasus-kasus yang dirasakan sebagai lebih kondusif memaklumi diri sendiri dan masa datang agar memperoleh ketentraman yang lebih sempurna.

Tugas utama guru bimbingan konseling ialah membantu peserta didik untuk menyelesaikan kasus kasus individual peserta didik yang berkaitan dengan pengelolaan pendidikan dan pengajaran. Karena itu, konselor diharapkan mempunyai keahlian akademik serta berpengalaman sebagai satu keutuhan, begitu juga tercantum dalam konstitusi rezim pendidikan nasional Nomor 27 Tahun 2008 dinyatakan ada 4 keahlian yang mesti dikuasai oleh seorang konselor, yaitu keahlian pedagogik, keahlian sosial, keahlian profesional, di antaranya ialah keahlian kepribadian yang merangkum beriman serta bertaqwa terhadap Tuhan Yang Maha Esa, menghormati dan menjunjung luhur harkat kemanusian, individualis, dan kemandirian menentukan, menunjukkan kredibilitas dan kestabilan budi pekerti yang kompeten serta memperlihatkan kapasitas yang berbobot tinggi. Maka perlu dilakukan persamaan persepsi akan pengetahuan peserta didik terhadap bimbingan konseling. Adapun untuk meningkatkan persepsi peserta didik terkait bimbingan dan konseling, di antaranya yaitu: penyelenggaraan seminar, pengembangan modul program bimbingan dan konseling, serta adanya kedekatan emosional antara guru bimbingan dan konseling serta peserta didik.

\section{Kesimpulan}

Dilihat dari hasil penelitian dan pembahasan dapat disimpulkan bahwa pengolahan data yang di dapatkan dari SMAN 1 BAB Tapan selaku pokok utama penelitian, didapatkan hasil bahwasanya jumlah peserta didik yang memilki persepsi sangat setuju terhadap bimbingan konseling yaitu sebesar 7,95\%, sebagain peserta didik lainnya memiliki persepsi setuju terhadap bimbingan konseling yaitu sebesar 52,27\%, peserta didik memilih persepsi sedang terhadap bimbingan konseling yaitu $32,95 \%$.

Jasa bimbingan dan konseling yang telah dilaksanakan di SMAN 1 BAB Tapan meliputi jasa penyesuaian, jasa informasi, jasa penyaluran, jasa bimbingan konseling perindividualis, jasa pngarahan konseling kelompok, serta mediasi. Aplikasinya sejauh ini belum optimal sehingga muncul beragam implementasi serta aktualisasi ditemukan atau diperoleh kesukaran yang dialami pihak sekolah. Mengenai itu, sekolah yang belum memadai masih keterbatasan saranar dan prsanarana jasa bimbingan konseling untuk meningkatkan berbagai akses jasa pengarahan konseling yang diberikan kepada peserta didik.

\section{Referensi}

[1] R. Sarfika, N. Afriyeni, Hermalinda, and F. Fernandes, "Pemberian Rational-Emotive Behavior Therapy dan Assertive Training Sebagai Upaya Mengurangi Perilaku Agresif Pada Remaja di Pauh Padang," J. Hilirisasi IPTEKS, vol. 3, no. 1, pp. 54-63, 2020.

[2] C. P. Bhakti, A. R. Kumara, and N. E. Safitri, "Pemahaman Guru Bimbingan dan Konseling," J. Ilm. Couns., vol. 7, no. 1, pp. 11-19, 2017. 
[3] R. Kumalasari and B. Susanto, "Pengaruh Layanan Informasi Bimbingan Konseling Berbantuan Media Audio Visual Terhadap Empati Siswa,” J. Ilm. Couns., vol. 7, no. 1, pp. 20-27, 2017.

[4] R. J. Sternberg, Psikologi Kognitif. Yogyakarta: Pustaka Pelajar, 2008.

[5] A. A. Ardiansyah, "Upaya bimbingan konseling nilai dan spiritual terhadap Transgender di Yogyakarta," Couns. J. Bimbing. dan Konseling, vol. 8, no. 2, p. 71, 2018, doi: 10.25273/ counsellia.v8i2.2568.

[6] L. Badriah, "Persepsi Peserta Didik terhadap Guru Bimbingan dan Konseling DI Madrasah Aliyah Ali Maksum," - Tajdid J. Ilmu Tarb., vol. 7, no. 1, pp. 16-30, 2018.

[7] H. Busmayaril, "Persepsi Peserta Didik terhadap Pelaksanaan Bimbingan dan Konseling di Sekolah Menengah Atas Negeri 1 Karya Penggawa Kabupaten Pesisir Barat," KONSELI J. Bimbing. dan Konseling, vol. 03, no. 1, pp. 11-18, 2016.

[8] S. Arikunto, Prosedur Penelitian. Jakarta: PT. Rineka Cipta, 2010.

[9] A. Tanzeh, Pengantar Metode penelitian. Yogyakarta: Teras, 2009.

[10] Sugiyono, Metode Penelitian Kuantitatif, Kualitatif dan R \& D. Bandung: Alfa Beta, 2018.

[11] Sugiyono, Metodologi Penelitian. Bandung: Alfabeta, 2017.

[12] Mahsun, Metode Penelitian Bahasa. Jakarta: PT. Raja Grafindo Persada, 2005.

[13] S. R. Utami, W. N. E. Saputra, S. P. Suardiman, and A. R. Kumara, "Peningkatan Self-Regulated Learning Siswa melalui Konseling Ringkas Berfokus Solusi," Couns. J. Bimbing. dan Konseling, vol. 10, no. 1, pp. 1-13, 2020, doi: 10.25273/counsellia.v10i1.4730.

[14] A. Sobur, Psikologi Umum. Bandung: Pustaka Setia, 2003.

[15] A. Sabri, Strategi Belajar Mengajar Micro Teaching. Ciputat: Quantum Teaching, 2007.

[16] Slameto, Belajar dan faktor-faktor yang Mempengaruhinya. Jakarta: PT. Rineka Cipta, 2010.

[17] M. Asrori and M. Ali, Psikologi Remaja Perkembangan Peserta Didik. Jakarta: PT Bumi Aksara, 2009.

[18] N. R. Siregar, "Persepsi Siswa Pada Pelajaran Matematika: Studi Pendahuluan Pada Siswa yang Menyenangi Game," Pros. Temu Ilm. X Ikat. Psikol. Perkemb. Indones., pp. 224-232, 2017.

[19] A. A. Saputra and B. Astuti, "Hubungan Antara Persepsi terhadap Layanan Bimbingan Belajar dengan Kemandirian Belajar Peserta Didik Sekolah Menengah Pertama," J. Kaji. Bimbing. dan Konseling, vol. 3, no. 1, pp. 41-48, 2018, doi: 10.17977/um001v3i12018p041.

[20] B. Walgito, Pengantar Psikologi Umum. Yogyakarta: C.V Andi, 2010.

[21] B. Walgito, Psikologi Sosial. Yogyakarta: C.V Andi, 2003.

[22] J. Rakhmat, Psikologi Komunikasi. Bandung: Rosdakarya, 2005.

[23] Prayitno and E. Amti, Dasar-Dasar Bimbingan dan Konseling. Jakarta: PT. Renika Cipta, 2008.

[24] D. Harris, Group Counseling With The Adolescent Offenders. Arkansas: University of Arkansas, 1995.

[25] A. Mappiere, Pengantar Bimbingan dan Konseling di Sekolah. Surabaya: Usaha Nasional, 1984.

[26] C. I. Zahara, "Hubungan Persepsi Siswa Terhadap Konselor Dan Sarana Prasarana Bimbingan Konseling Dengan Minat Layanan Konseling Di SMP Negeri 2 Dewantara Kabupaten Aceh Utara," J. MAGISTER Psikol. UMA, vol. 9, no. 1, pp. 10-20, 2017. 